\title{
RELEVANSI PUTUSAN HAKIM DALAM PENYELESAIAN TINDAK PIDANA LALU LINTAS
}

\author{
Zuleha \\ Dosen Fakultas Hukum Universitas Samudra, Langsa - Aceh \\ zuleha.izzan@gmail.com
}

\begin{abstract}
The occurrence of traffic accidents caused many casualties, died then for the perpetrators can be charged with murder for negligence or negligence in driving a motor vehicle. The application is regulated in Law Number 22 Year 2009 on Traffic and Road Transportation. But in some traffic accidents that already have a permanent legal force in the District Court, the sentences handed down by the panel of judges to my custodian who committed the crime because of his negligence are still many that do not refer to the provisions of the Act. The result of the research of the factors causing the judge's decision is not in accordance with the provisions of the law in the case of traffic accidents is the existence of the police who allow the peace of traffic crimes, In the application of law against traffic accidents that is, the judge's decision on traffic accidents, minimum prison
\end{abstract}

Keywords: Implementation, Traffic and Road Transport, Traffic Accident.

\begin{abstract}
Abstrak,Terjadinya kecelakaan lalu lintas banyak menimbulkan korban, meninggal dunia maka bagi pelaku bisa dijerat dengan pembunuhan karena kealpaan atau kelalaian dalam mengemudikan kendaraan bermotor. Penerapan tersebut diatur dalam Undang-Undang Nomor 22 Tahun 2009 Tentang Lalu Lintas dan Angkutan Jalan. Namun dalam beberapa perkara kecelakaan lalu lintas yang sudah mempunyai kekuatan hukum tetap di Pengadilan Negeri, hukuman yang dijatuhkan majelis Hakim kepada sipelaku yang melakukan tindak pidana karena kelalaianya masih banyak yang tidak mengacu pada ketentuan Undang-undang. Hasil kajian menunjukkan bahwa dari faktor penyebab putusan hakim tidak sesuai dengan ketentuan undang-undang dalam perkara kecelakaan lalu lintas adalah adanya pihak kepolisian yang memperbolehkan perdamaian tindak pidana Ialu lintas, Dalam penerapan hukum terhadap kecelakaan lalu lintas yaitu, putusan majelis hakim terhadap kecelakaan lalu lintas, menjatuhkan pidana penjara minimum.
\end{abstract}

Kata Kunci : Penerapan, Lalu Lintas dan Angkutan Jalan, Kecelakaan Lalu Lintas.

\section{Pendahuluan}

Perkembangan alat transportasi semakin lama bukannya berkurang melainkan semakin bertambah, apalagi ditambah dengan berbagai macam jenis dan bentuk alat transportasi baru dengan berbagai macam mode, bentuk serta keunggulannya masingmasing. Akan tetapi, pertambahan jumlah transportasi tidak diimbangi dengan kondisi jalan yang baik dan juga kesadaran masyarakat tentang aturan berkendara. Karena, kurang berhati-hatinya para pengguna jalan juga dapat mempengaruhi tinggi rendahnya angka kecelakaan yang terjadi dijalan raya, baik yang menyebabkan orang lain meninggal dunia maupun hanya menyebabkan korban luka-luka.

Pemerintah sebagai penyelenggara negara, turut berupaya untuk meminimalisir tingginya angka kecelakaan di Indonesia. Melalui program dekade keselamatan jalan 
2011-2020, yang dicanangkan oleh Wakil Presiden di Jakarta pada 20 Juni 2011 lalu, pemerintah menargetkan penurunan fatalitas hingga 50 persen pada $2020 .{ }^{1}$

Banyaknya korban meninggal dalam kasus kecelakaan dikategorikan sebagai pembunuhan karena kealpaan atau kelalaian, karena pembunuhan dalam konteks hukum pidana positif dikategorikan atas pembunuhan yang dikehendaki oleh pelaku, pembunuhan karena penganiayaan dan pembunuhaan karena kealpaan atau kelalaian. Maksud dari pembunuhan karena kealpaan atau kelaian itu sendiri adalah suatu perbuatan tindak pidana yang dilakukan oleh seseorang yang bukan karena kehendaknya untuk melakukan tindak pidana tersebut. Tetapi karena ketidak hati-hatiannya sehingga mengakibatkan orang lain jadi korban. Jadi, pengendara tidak dikategorikan masuk kedalam unsur kesengajaan tetapi masuk dalam unsur kelalaian. ${ }^{2}$

Rumusan "karena salahnya" adalah unsur "kelalaian" atau culpa yang menurut ilmu hukum pidana terdiri dari; (a). Culpa dengan kesadaran, dan (b). Culpa tanpa kesadaran. ${ }^{3}$ Kecelakaan lalu lintas yang menimbulkan banyak korban maka pelakunya bisa dijerat dengan pembunuhan karena kealpaan atau kelalaian dalam mengemudikan kendaraan bermotor diatur dalam Undang-Undang Nomor 22 Tahun 2009 Tentang Lalu Lintas dan Angkutan Jalan.

Definisi kecelakaan lalu lintas menururt Peraturan Pemerintah Nomor 43 Tahun 1993 tentang Prasarana dan Lalu Lintas Jalan, pada Pasal 93 ayat (1) dari ketentuan tersebut mendefinisikan kecelakaan lalu lintas adalah : "Suatu peristiwa dijalan baik disangka-sangka dan tidak disengaja melibatkan kendaraan dengan atau tanpa pemakai jalan lainnya, mengakibatkan korban manusia atau kerugian harta benda”.

Kecelakaan lalu lintas merupakan peristiwa yang tidak diduga dan tidak disengaja yang melibatkan kendaraan atau pengguna jalan lain yang dapat menimbulkan korban dan/atau kerugian harta benda. Kecelakaan lalu lintas bisa terjadi kapan saja dan dimana saja, tidak bisa diprediksi. Kecelakaan lalu lintas tidak hanya dapat menimbulkan trauma, cidera, luka ringan, luka berat atau kecacatan melainkan dapat mengakibatkan meinggal dunia. $^{4}$

Kecelakaan lalu lintas menurut Fachrurrozy sebagaimana yang dikutip oleh Antory merupakan seuatu peritstiwa yang tidak disangka-sangka dan tidak disengaja melibatkan kendaraan dengan atau tanpa pemakai jalan lainnya, mengakibatkan korban manusia (mengalami luka ringan, luka berat, dan meninggal) dan kerugian harta benda. ${ }^{5}$

Dalam undang-undang ini juga diatur mengenai hak, kewajiban serta tanggungjawab para penyedia jasa terhadap kerugian pihak ketiga sebagai akibat dari

1 Kecelakaan Lalu Lintas Menjadi Pembunuh Terbesar Ketiga", http://www.bin.go.id/awas/detil/197/4/21/03/2013/kecelakaan-lalu-lintas-menjadi-pembunuhterbesar-ketiga, diakses pada tanggal 11 Februari 2016

2 P.A.F. Lamintang dan Theo Lamintang, Delik-Delik Khusus: Kejahatan Terhadap Nyawa, Tubuh, dan Kesehatan, Sinar Grafika, Jakarta, 2012, hlm. 43

${ }^{3}$ Leden Marpaung, Tindak Pidana Terhadap Nyawa dan Tubuh, Sinar Grafika, Jakarta, 2000, hlm. 65

${ }^{4}$ C.S.T, Kansil dan Christine S.T. Kansil, Disiplin Berlalu Lintas di Jalan Raya, Jakarta, Rineka Cipta, 1995, hlm. . 35

5 Antory Royan Dyan, Pranata Hukum, Jurnal Ilmu Hukum program Studi Magister Ilmu Hukum Program Pascasarjana Universitas Bandar Lampung, vol 7 No. 1, Januari 2012 hlm 27 
penyelenggaraan angkutan jalan. Karena dalam perkembangannya, pelaku tindak pidana lalu lintas jalan ini berkewajiban memberikan santunan kepada korbannya. Memang santunan bagi korban tindak pidana lalu lintas jalan pada saat ini seperti sudah menjadi kewajiban, apalagi jika sipelaku adalah orang yang mempunyai kedudukan ekonomi kuat atau dengan kata lain mempunyai uang yang lebih.

Dari uraian diatas, hukuman yang dijatuhkan majelis Hakim kepada sipelaku yang melakukan tindak pidana karena kelalaianya menyebabkan timbulnya korban banyak yang tidak sesuai sebagaimana yang tercantum dalam Pasal 310 butir (4) Undang-Undang Nomor 22 Tahun 2009 Tentang Lalu Lintas dan Angkutan Jalan, yang mempunyai ancaman pidana dengan pidana penjara paling lama 6 (enam) tahun dan denda paling banyak Rp. 12.000.000,00 (dua belas juta rupiah).

Berdasarkan latar belakang masalah yang telah diuraikan diatas, maka permasalahan yang akan dibahas adalah sebagai berikut:

1. Apa faktor penyebab putusan hakim terhadap kasus kecelakaan lalu lintas yang menyebabkan matinya orang tidak sesuai dengan ketentuan undang-undang?

2. Bagaimana penerapan hukum terhadap kasus kecelakaan lalu lintas yang menyebabkan matinya orang?

Adapun tujuan dari kajian ini yaitu hendak mengkaji dan mengetahui faktor penyebab putusan hakim terhadap kasus kecelakaan lalu lintas yang menyebabkan matinya orang tidak sesuai dengan ketentuan undang-undang. Dan, untuk mengetahui penerapan hukum terhadap kasus kecelakaan lalu lintas yang menyebabkan matinya orang.

\section{Tinjauan Pustaka}

Di era modern seperti sekarang ini, bidang transportasi berperan penting dalam kesejahteraan masyarakat sehingga mendukung pertumbuhan di berbagai bidang. Kemajuan ilmu pengetahuan dan teknologi mendukung perkembangan alat transportasi secara pesat, sehingga menyebabkan laju pertumbuhan kendaraan semakin meningkat. Perkembangan kendaraan sebagai alat transportasi membawa dampak positif bagi pemenuhan dan peningkatan kesejahteraan manusia, terutama sebagai alat mobilisasi guna memperlancar aktivitas sehari-hari. Namun hal ini juga diiringi dengan timbulnya beberapa dampak negatif yang tidak diinginkan, seperti kemacetan dan meningkatnya angka kecelakaan lalu lintas. ${ }^{6}$

Equality before the law merupakan salah satu asas penting dalam hukum modern, dimana ini menjadi salah satu sendi doktrin Rule of Law yang di negara berkembang seperti Indonesia, sehingga asas ini dijadikan landasan oleh setiap manusia dalam melakukan penegakan hukum. Makin meningkatnya aktivitas lalu lintas memicu peningkatan masalah yang berhubungan dengan lalu lintas, salah satunya dalah kecelakaan lalu lintas. Masalahnya adalah sulit dalam memberikan penegakan hukum yang dapat menimbulkan efek jera sehingga timbul kesadaran berlalu lintas. ${ }^{7}$

${ }^{6}$ Marsaid, M.Hidayat, Ahsan, Faktor Yang Berhubungan Dengan Kejadian Kecelakaan Lalu Lintas Pada Pengendara Sepeda Motor Di Wilayah Polres Kabupaten Malang, Jurnal Ilmu Keperawatan - Volume 1, No. 2, Nopember 2013, hlm. 99

7 Muhammad Dani Hamzah, Penegakan Hukum Pada Kasus Tindak Pidana Kecelakaan Lalu Lintas Yang Menyebabkan Hilangnya Nyawa Orang, Jurnal Daulat Hukum, Vol. 1. No. 1 Maret 2018, hlm. 43 
Lalu lintas di Indonesia diatur dalam peraturan perundang-undangan yaitu Undang-Undang Nomor 22 tahun 2009 tentang Lalu Lintas dan Angkutan Jalan, dimana peraturan tersebut dibuat guna menjamin keamanan, ketertiban dan kesejahteraan dalam masyarakat yang perlu ditentukan mengenai tindakan yang dilarang dan diharuskan. Sedangkan pelanggaran dari ketentuan tersebut diancam dengan pidana. Sering terjadinya pelanggaran lalu lintas, baik yang disengaja maupun yang tidak disengaja mungkin disebabkan karena sanksi yang dijatuhkan kepada para pelaku pelanggaran lalu lintas tersebut terlalu ringan, maka tidak heran jika kian hari kian banyak terjadi peristiwa pelanggaran lalu lintas. Akibat hukum dari kecelakaan lalu lintas adalah adanya sanksi pidana bagi si pembuat atau penyebab terjadinya peristiwa itu dan dapat pula disertai tuntutan perdata atas kerugian material yang ditimbulkan. ${ }^{8}$

Kecelakaan lalu lintas adalah suatu peristiwa di jalan yang tidak diduga dan tidak disengaja melibatkan kendaraan dengan atau tanpa pengguna jalan lain yang mengakibatkan kerugian dan/atau kerugian harta benda. Sedangkan menurut Kamus Besar Bahasa Indonesia pengertian kecelakaan adalah kejadian (peristiwa) yang menyebabkan orang celaka.

Kebiasaan dalam praktek di masyarakat, para pihak yang terlibat kecelakaan seringkali melakukan penyelesaian sendiri masalah ganti kerugian tersebut, dengan memberikan ganti kerugian, santunan, bantuan kepada pihak yang dianggap sebagai korban (yang lebih menderita) secara sukarela, bahkan kadang tidak mempersalahkan salah benarnya. Kebiasaan tersebut diibaratkan dalam sebuah perdamaian yang mana antara si korban dan si pelaku bersama-sama duduk dalam satu pertemuan untuk samasama berbicara

Ada beberapa faktor yang mengakibatkan kecelakaan lalu lintas tersebut seperti faktor manusia, faktor kendaraan dan faktor jalan itu sendiri. Kombinasi ketiga faktor ini dapat saja terjadi, antara manusia dengan kendaraan misalnya berjalan melebihi batas kecepatan yang ditetapkan kemudian ban pecah sehinggan mengalami kecelakaan lalu lintas. Setiap pengguna jalan wajib turut serta terlibat dalam menciptakan situasi yang kondusif dan lalu lintas yang tertib dan lancar. Ketertiban lalu lintas merupakan keadaan dimana manusia dalam mempergunakan jalan secara teratur, tertib dan lancar atau bebas dari kejadian kecelakaan lalu lintas. Maka dalam hal ini diperlukan aturan hukum yang dapat mengatur lalu lintas untuk mewujudkan ketertiban dalam berlalu lintas. Diharapkan peraturan yang ada saat ini dapat menjadi pedoman dalam mengantisipasi terjadinya permasalahan lalu lintas dan kecelakaan yang dapat mengakibatkan kerugian materi maupun korban jiwa. ${ }^{10}$

Berdasarkan ketentuan hukum yang berlaku di Indonesia, perbuatan yang menimbulkan kerugian pada pihak korban dapat diproses menurut hukum baik secara perdata maupun pidana umum. Adapun tindak pidana berbeda hakikatnya dengan perbuatan melawan hukum dalam konteks perdata. Namun, kesamaan antara keduanya merupakan salah (wrong) dan masing-masing merupakan pelanggaran terhadap larangan hukum (commission) atau terhadap kewajiban hukum (omission). Apabila pelanggaran tersebut menimbulkan konsekwensi pidana yang dilekatkan pada pelanggaran itu, maka pelanggaran itu merupakan tindak pidana. Konsekwensi pidana yang dimaksud adalah

${ }^{8}$ Ibid., hlm. 44

9 Adib Bahari, Tanya Jawab Aturan Wajib Berlalu Lintas, Pustaka Yustisa, Yogyakarta, 2010, hlm. 65

${ }^{10}$ Rizki Prananda Tambunan, Tinauan Yuridis Terhadap Penerapan Konsep Restorative Justice Dalam Kecelakaan Lalu Lintas, Jurnal, Fakultas Hukum Universitas Sumatera Utara, 2014, hlm. 3 
berupa tuntutan secara pidana di muka pengadilan pidana dan dijatuhi sanksi pidana bila terbukti bersalah. ${ }^{11}$

Dalam sistem peradilan pidana korban merupakan subyek yang terlupakan. Bahkan korban tindak pidana sering menjadi korban kedua setelah selesainya proses peradilan pidana, itulah sebabnya korban tindak pidana mengalami trauma seumur hidup karena peristiwa yang menimpa dirinya. Ketika peristiwa itu mengalami proses untuk menuju keadilan ia harus menjadi saksi, menjadi subyek yang penting dalam menemukan dan membuat titik terang dari terjadinya tindak pidana, maka tidak heran jika korban adalah unsur penting dalam teori segitiga di Kepolisian, dan bila proses itu memasuki tahap berikutnya maka ia menjadi saksi di Pengadilan dengan biaya sendiri dan menceritakan kejadian itu di Pengadilan secara berulang-ulang dan bila telah berakhir dengan adanya keputusan hakim, korban tidak mendapatkan apa-apa atau tidak mendapatkan kompensasi atau restitusi. ${ }^{12}$

Mengenai sistem penegakan hukum menjelaskan bahwa kegiatan menyerasikan hubungan nilai-nilai yang terjabarkan dalam kaidah-kaidah atau pandangan-pandangan menilai yang mantap dan mengejawantah dan sikap tindak sebagai rangkaian penjabaran nilai tahap akhir, untuk menciptakan fungsi hukum sebagai social engineering, memelihara dan mempertahankan sebagai social control kedamaian pergaulan hidup.

Sehubungan dengan tujuan pemidanaan, Barda Nawawi Arief berpendapat bahwa pemidanaan bertujuan untuk pemedinaan bertujuan untuk pembebasan dan makna pembebasan menghendaki agar sipelaku bukan saja harus dibebaskan dari alam pikiran yang jahat dan keliru, melainkan harus dibebaskan juga dari kenyataan sosial ,dimana pelaku terbelenggu. ${ }^{13}$

Menurut Andi Hamzah, Kesalahan dan pertanggungjawaban pidana dalam pengertian hukum pidana dapat disebut ciri atau unsur kesalahan dalam arti yang luas:

a. Dapat dipertanggungjawabkan pembuat.

b. Adanya kaitan psikis antara pembuat dan perbuatan, yaitu adanya sengaja atau kesalahan dalam arti sempit (culpa).

c. Tidak adanya dasar peniadaan pidana yang menghapus dapatnya dipertanggungjawabkan sesuatu perbuatan kepada pembuat. ${ }^{14}$

Seperti telah diketahui Kitab Undang-Undang Hukum Pidana sekarang belum memberikan rincian secara jelas mengenai pedoman hakim dalam menjatuhkan pidana, melainkan hanya merupakan aturan pemberian pidana yang dapat dijadikan pedoman bagi hakim dalam menjatuhkan sanksi pidana. Kedudukan hakim sebagai pelaksana keadilan ditunjang dari pengetahuan yang cukup tentang pemidanaan terutama untuk mencapai pertimbangan-pertimbangan yang matang sebelum hakim menjatuhkan hukuman pada pelaku tindak pidana berkenaan dengan penjatuhan pidana.

\footnotetext{
${ }^{11}$ Mustafa Abdullah, Sosiologi Hukum Dalam Masyarakat, Rajawali, Jakarta, 1998, hlm. 97

${ }^{12}$ Ibid, hlm. 93

${ }^{13}$ Barda Nawawi Arief, Kebijakan Sanksi Pidana Dalam Menanggulangi Kejahatan, Fakultas Hukum Undip, Semarang, 2003, hlm. 31

${ }^{14}$ Andi Hamzah, Pengantar Hukum Pidana Indonesia, Ghalia Indonesia, Jakarta, 1983, hlm. 73
} 


\section{Pembahasan}

\section{Faktor Penyebab Putusan Hakim Terhadap Kasus Kecelakaan Lalu Lintas Tidak Sesuai Dengan Ketentuan Undang-Undang}

Pertanggungjawaban pidana penyelenggara jalan dalam kecelakaan lalu lintas yang mengakibatkan orang lain meninggal dunia, secara tegas diatur dalam ketentuan Pasal 273 Undang-Undang No. 22 Tahun 2009 tentang Lalu Lintas dan Angkutan jalan, yang berbunyi sebagai berikut :

Ayat (1) : setiap penyelenggara jalan yang tidak dengan segera dan patut memperbaiki jalan yang rusak yang mengakibatkan kecelakaan lalu lintas sebagaimana dimaksud dalam Pasal 24 ayat (1) sehingga menimbulkan korban luka ringan dan/atau kerusakan kendaraan dan/atau barang dipidana dengan penjara paling lama (enam) bulan atau denda paling banyak Rp 12.000.000,00 (dua belas juta rupiah).

Ayat (2) : dalam hal pebuatan sebagaimana dimaksud pada ayat (1) mengakibatkan luka berat, pelaku dipidana dengan pidana penjara paling lama 1 (satu) tahun atau denda paling banyak Rp 24.000.000, 00 (dua puluh empat juta rupiah).

Ayat (3) : dalam hal perbuatan sebagaimana dimaksud pada ayat (1) mengakibatkan orang lain meninggal 65 dunia, pelaku dipidana dengan pidana penjara paling lama 5 (lima) tahun atau denda paling banyak Rp 120.000.000,00 (seratus dua puluh juta rupiah).

Ayat (4) : penyelenggara jalan yang tidak memberi tanda atau rambu pada jalan yang rusak dan belum diperbaiki sebagaimana dimaksud dalam Pasal 24 ayat (2) dipidana dengan pidana penjara paling lama 6 (enam) bulan atau denda paling banyak Rp 1.500.000,00 (satu juta lima ratus ribu rupiah).

Menurut ketentuan Pasal 273 tersebut di atas, secara jelas dan tegas dapat dikatakan bahwa penyelenggara jalan harus mempertanggungjawabkan akibat hukum yang terjadi dari kecelakaan lalu lintas jalan yang disebabkan karena kerusakan jalan sehingga mengakibatkan orang lain meninggal dunia.

Namun disisi lain kecelakaan lalu lintas dapat terjadi akibat adanya unsur kelalaian dari pengguna jalan sendiri sehingga mengakibatkan kecelakan, baik yang menyebabkan luka ringan, luka berat maupun meninggalnya salah satu pengguna jalan. Berdasarkan hasil penelitian terdapat beberapa faktor-faktor penyebab putusan hakim terhadap kasus kecelakaan lalu lintas tidak sesuai dengan ketentuan undang-undang adalah sebagai berikut:

a. Adanya Pihak kepolisian Yang Memperbolehkan Perdamaian Tindak Pidana Lalu Lintas.

Besarnya tingkat pelanggaran lalu lintas tersebut lebih banyak dilakukan oleh pelajar maupun siswa yang tidak memperhatikan rambu-rambu lintas. Namun tidak sedikit juga pelajar dan siswa yang menjadi korban baik kecelakaan lalu lintas maupun pelanggaran lalu lintas. Kondisi itu menunjukkan bahwa persentase kenaikan kasus pelanggaran lalu lintas dari tahun ke tahun semakin meningkat.

Akibat hukum dari kecelakaan lalu lintas adalah adanya pidana bagi si pembuat atau penyebab terjadinya peristiwa itu dan dapat pula disertai tuntutan perdata atas 
kerugian material yang ditimbulkan. Sebagaimana dinyatakan oleh Andi Hamzah, bahwa "Dalam berbagai macam kesalahan, di mana orang yang berbuat salah menimbulkan kerugian pada orang lain, maka ia harus membayar ganti kerugian. ${ }^{15}$

Perdamaian kecelakaan lalu lintas dapat dilihat bahwa aspek perdamaian di lokasi kecelakaan masih sering dilakukan. Hal tersebut bertujuan untuk mengurangi penumpukan perkara di pengadilan. Penyelesaian kecelakaan lalu lintas dilakukan secara damai.

Pelaksanaan perdamaian tindak pidana lalu lintas yang diselesaikan di tingkat kepolisian dilakukan dengan alasan penyelesaian dilakukan secara kekeluargaan dan pihak yang dirugikan hanya terkena luka ringan, sehingga pelaku tindak pidana meminta penyelesaian dilakukan secara damai. Oleh sebab itu, pihak kepolisian hanya memfasilitasi kedua belah pihak. Pihak kepolisian yang memfasilitasi pihak yang berperkara dengan alasan supaya para pihak cepat menyelesaikan sengketa yang terjadi. Selain itu, pihak kepolisian melihat sebelum tertulis surat perdamaian dengan adanya biaya kompensasi yang diberikan oleh pihak pelaku kepada korban senilai dengan harga kerugian yang diderita oleh korban. Alasan pihak kepolisian melakukan perdamaian tindak pidana lalu lintas berdasarkan Surat Kapolri No. Pol: B/3022/XII/2009/SDEOPS, tanggal 14 Desember 2009 tentang Penanganan Kasus Melalui Alternatif Dispute Resolusion (ADR).

b. Perdamaian Yang Dilakukan Pelaku Kecelakaan Yang Berkaitan Dengan Korban Tindak Pidana Lalu Lintas.

Sanksi Ganti kerugian, merupakan suatu sanksi yang mengharuskan seseorang yang telah bertindak merugikan orang lain untuk membayar sejumlah uang ataupun barang pada orang yang dirugikan, sehingga kerugian yang telah terjadi dianggap tidak pernah terjadi. Dewasa ini sanksi ganti kerugian tidak hanya merupakan bagian dari hukum perdata, tetapi juga telah masuk ke dalam hukum Pidana. Perkembangan ini terjadi karena semakin meningkatnya perhatian masyarakat dunia terhadap korban tindak pidana.

Dengan demikian akan mengembalikan sistem kepercayaan korban dalam menghadapi kehidupan. Demikian pula akan membebaskan rasa bersalah terpidana yang dapat membuatnya tertekan dan justru berbahaya serta dapat merugikan dirinya atau masyarakat. Disamping itu secara psicologis dengan diterimanya uang ganti kerugian tersebut oleh korban berarti korban dapat dikatakan telah memberikan maaf pada pelaku tindak pidana tersebut.

Pengurangan pidana dalam pelanggaran lalu lintas juga dilakukan oleh pihak pelaku dan pihak korban dengan cara menetapkan surat kuasa hukum pada pihak pengacara.

c. Pemberian Santunan Sebagai Bentuk Perdamaian Dari Pelaku Tindak Pidana Lalu Lintas.

Pelaku tindak pidana lalu lintas banyak yang memberikan santunan kepada korbannya. Santunan bagi korban tindak pidana lalu lintas pada saat ini seperti sudah

${ }^{15}$ Rizki Prananda Tambunan, Tinauan Yuridis Terhadap Penerapan Konsep Restorative Justice Dalam Kecelakaan Lalu Lintas ... hlm. 3 
menjadi kewajiban, apalagi jika pembuat tindak pidananya adalah orang yang mempunyai kedudukan ekonomi kuat atau mempunyai uang yang berlebih. Pada proses persidangannya sendiri hakim akan selalu menanyakan kepada pembuat tindak pidana lalu lintas jalan, apakah sudah memberikan santunan kepada korban atau keluarganya. Hal ini disebabkan korban tindak pidana lalu lintas jalan umumnya mengalami luka-luka atau luka berat, sehingga harus dirawat di rumah sakit yang memerlukan biaya, maupun yang meninggal dunia memerlukan biaya pemakaman. Santunan memang tidak akan mengembalikan nyawa seseorang yang telah meninggal tetapi pemberian santunan sangat bermanfaat terutama jika korban meninggal tindak pidana lalu lintas tersebut adalah orang yang menjadi tulang punggung keluarga. ${ }^{16}$

Selain itu pemberian santunan yang dikeluarkan oleh pihak pelaku, juga dikeluarkan oleh pihak PT. Jasa Raharja. Jenis santunan yang diberikan PT. Jasa Raharja berupa santunan meninggal dunia dengan jenis alat-alat angkutan darat sebesar Rp. 25 juta. Jenis santunan cacat tetap untuk jenis angkutan darat maksimal diberikan sebesar Rp. 25 juta. Adapun jenis santunan yang dikeluarkan oleh pihak PT. Jasa Raharja meliputi penggantian biaya rawatan dan pengobatan (sesuai ketentuan), Santunan kematian dan Santunan cacat tetap.

\section{B. Penerapan Hukum Terhadap Kecelakaan Lalu Lintas}

Hakim mempunyai kebebasan untuk menentukan berat ringannya pidana yang akan dijatuhkan terhadap pelaku tindak pidana. Namun walaupun hakim mempunyai kebebasan serta batas keyakinan sendiri untuk memberikan penilaian terhadap perkara yang diperiksa, hakim juga harus memperhatikan persoalan yang nyata terhadap syaratsyarat yang ditetapkan oleh Undang-undang. ${ }^{17}$

Majelis hakim perlu mempertimbangkan hal-hal memberatkan dan yang meringankan pada kasus tindak pidana kecelakaan lalu lintas yang diatur dalam UndangUndang Nomor 22 tahun 2009 Tentang Lalu Lintas dan Angkutan Jalan

1. Hal-hal yang memberatkan pidana dari terdakwa.

Perbuatan terdakwa mengakibatkan orang lain meninggal dunia.

2. Hal-hal yang meringankan pidana dari terdakwa.

a. Terdakwa belum pernah di hukum.

b. Terdakwa bersikap sopan dan tidak mempersulit jalannya pemeriksaan dipersidangan.

Menurut Pasal 310 butir (1) Undang-Undang Nomor 22 tahun 2009 Tentang Lalu Lintas dan Angkutan Jalan, yang mana ancaman pidana yang dilakukan pelaku tindak pidana kecelakaan lalu lintas yang menyebabkan matinya orang diancam pidana maksimal 6 (enam) tahun penjara, tetapi dalam kenyataan yang sering terjadi dalam tindak pidana pelanggaran lalu lintas hakim menjatuhkan hukuman pidana penjara

${ }^{16}$ Abd. Wahid, Tinjauan Hukum Terhadap Santunan Bagi Keluarga Korban Meninggal Atau Luka Akibat Kecelakaan Lalu Lintas Menurut Undang-Undang No. 22 Tahun 2009, Jurnal Ilmu Hukum Legal Opinion, Edisi 3, Volume 1, 2013, hlm. 8

${ }^{17}$ Yusi Amdani, Implikasi Penafsiran Undang-Undang oleh Hakim Praperadilan Dalam Perkara Tindak Pidana Korupsi, Jurnal Mimbar Hukum, Vol. 27, No. 3, 2015, hlm. 462 
minimum. Apabila dikaitkan dengan teori penerapan pidana, maka terhadap penerapan hukumannya tidak diterapkan secara maksimum atas tindak pidana kecelakaan lalu lintas.

Teori gabungan (integratif) adalah salah satu dari teori penerapan pidana pada asas pembalasan dan asas tertib pertahanan tata tertib masyarakat, dengan kata lain dua alasan itu menjadi dasar dari penjatuhan pidana. Pada dasarnya teori gabungan adalah gabungan teori absolut dan teori relatif. Gabungan kedua teori mengajarkan bahwa penjatuhan hukuman adalah untuk mempertahankan tata tertib hukum dalam masyarakat dan memperbaiki pribadi si penjahat.

Teori gabungan ini dapat dibedakan menjadi dua golongan besar, yaitu :

1. Teori gabungan yang mengutamakan pembalasan, tetapi pembalasan itu tidak boleh melampaui batas dari apa yang pelu dan cukup untuk dapatnya dipertahankannya tata tertib masyarakat;

2. Teori gabungan yang mengutamakan perlindungan tata tertib masyarakat, tetapi penderitaan atas dijatuhinya pidana tidak boleh lebih berat daripada perbuatan yang dilakukan terpidana. ${ }^{18}$

Menurut ketentuan Pasal 273 ayat (3) Undang-Undang No. 22 Tahun 2009, menyatakan dalam hal perbuatan sebagaimana dimaksud pada ayat (1) mengakibatkan orang lain meninggal dunia, pelaku dipidana dengan pidana penjara paling lama 5 (lima) tahun atau denda paling banyak Rp 120.000.000,00 (seratus dua puluh juta rupiah). Penjatuhan pidana terhadap penyelenggara jalan berdasarkan Pasal tersebut bersifat alternatif artinya hakim dalam menjatuhkan pidana dapat memilih. Hal ini dapat dilihat dalam Pasal 273 ancaman terdapat frase kata "atau", misalnya pidana penjara atau pidana denda saja

Penyelesaian perkara tindak pidana kecelakaan lalu lintas yang menggunakan undang-undang no. 22 tahun 2009 tentang Lalu lintas dan Angkutan adalah mengikuti pola pikir paham positivis jalan pikiran paham positivis sebagaimana yang telah kita bicarakan di atas. Adalah bertengan dengan pola berfikirnya cita hukum Pancasila. Hukum dalam cita hukum Pancasila sarat akan nilai moral, nilai Ketuhanan. Yang dimaksud dengan cita hukum adalah gagasan, karsa, cipta dan pikiran berkenaan dengan hukum atau persepsi tentang makna hukum yang dalam intinya terdiri atas tiga unsur: keadilan, kehasil gunaan dan kepastian hukum. Dalam paham positivis hukum berintikan ketertiban dan kepastian.

Model penyelesaian perkara pidana kelalai lalu lintas, polisi masih melakukan penegakan hukum dengan pendekatan hukum positif, namun demikian masyarakat sudah ada kesadaran utuk menyelsaikan perkara ini dengan peyelesaian diluar peradilan pidana dengan melakukan perdamaian yaitu memberikan santunan kepada korban, dalam bentuk menanggung segala biaya pengobatan bagi korban luka-luka dan biaya kematian bagi korban yang mati.

${ }^{18}$ Adami Chazawi, Pelajaran Hukum Pidana I, Jakarta : PT. Raja Grafindo, 2010, Hlm 162-163. 


\section{Penutup}

\section{Kesimpulan}

Berdasarkan uraian dari hasil penelitian dan pembahasan, maka dapat disimpulkan bahwa:

Faktor penyebab putusan hakim terhadap kecelakaan lalu lintas tidak sesuai dengan ketentuan undang-undang adalah adanya pihak kepolisian yang memperbolehkan perdamaian tindak pidana kecelakaan lalu lintas di jalan raya, adanya perdamaian yang dilakukan oleh pelaku tindak pidana kecelakaan lalu lintas, serta adanya pemberian santunan sebagai bentuk perdamaian dari pelaku tindak pidana kecelakaan lalu lintas.

Penerapan hukum terhadap kecelakaan lalu lintas majelis hakim menjatuhkan pidana penjara minimum. Apabila dikaitkan dengan teori penerapan pidana, maka terhadap penerapan hukumannya tidak diterapkan secara maksimum atas tindak pidana kecelakaan lalu lintas.

\section{Saran}

Dalam penjatuhan hukuman terhadap pelaku pelanggaran lalu lintas yang menyebabkan matinya orang, hakim harus mempertimbangkan kepada faktor-faktor kelalaian pelaku, karena tidak sama semua kecelakaan yang terjadi atas faktor kelalaian pelaku.

Diharapkan kepada para penegak hukum khususnya kepada penyidik kepolisian dalam menyidik serta penuntut umum dalam merumuskan surat dakwaan terhadap suatu kasus, hendaknya memperhatikan asas-asas dalam hukum pidana serta mengikuti perkembangan peraturan perundang-undangan. Karena hukum itu tidak statis akan tetapi dinamis, selalu mengalami perubahan mengikuti peradaban manusia.

\section{Daftar Pustaka}

Adami Chazawi, Pelajaran Hukum Pidana I, Jakarta : PT. Raja Grafindo, 2010

Adib Bahari, 125 Tanya Jawab Aturan Wajib Berlalu Lintas, Pustaka Yustisa, Yogyakarta, 2010

Andi Hamzah, Pengantar Hukum Pidana Indonesia, Ghalia Indonesia, Jakarta, 1983

Barda Nawawi Arief, Kebijakan Sanksi Pidana Dalam Menanggulangi Kejahatan, Fakultas Hukum Undip, Semarang, 2003

Lamintang P.A.F., dan Theo Lamintang, Delik-Delik Khusus: Kejahatan Terhadap Nyawa, Tubuh, dan Kesehatan, Sinar Grafika, Jakarta, 2012 
Volume 13, Nomor 1, Januari-Juni 2018

Leden Marpaung, Tindak Pidana Terhadap Nyawa dan Tubuh, Sinar Grafika, Jakarta, 2000

Mustafa Abdullah, Sosiologi Hukum Dalam Masyarakat, Rajawali, Jakarta, 1998

Abd. Wahid, Tinjauan Hukum Terhadap Santunan Bagi Keluarga Korban Meninggal Atau Luka Akibat Kecelakaan Lalu Lintas Menurut Undang-Undang No. 22 Tahun 2009, Jurnal Ilmu Hukum Legal Opinion, Edisi 3, Volume 1, 2013

Yusi Amdani, Implikasi Penafsiran Undang-Undang oleh Hakim Praperadilan Dalam Perkara Tindak Pidana Korupsi, Jurnal Mimbar Hukum, Vol. 27, No. 3, 2015

Kecelakaan Lalu Lintas Menjadi Pembunuh Terbesar Ketiga", http://www.bin.go.id/awas/detil/197/4/21/03/2013/kecelakaan-lalu-lintasmenjadi-pembunuh-terbesar-ketiga, diakses pada tanggal 11 Februari 2016 